\title{
遺伝子組み替え作物と多国籍企業ネットワークの相互的構築
}

\section{An Interactive Construction of Transgenic Crops and Multinational Corporation Networks}

\section{大塚 善樹 OTSUKA Yoshiki}

The new techno-economic system of "information capitalism" may be characterized by interactive constructions between technology networks of products and global capital networks of organizations via the medium of an intellectual property system. This paper examines this hypothesis by using a recent example of new technology construction that has given rise to transgenic crops. In parallel with the technology, two other social relations have emerged: (1) organizational networks of multinational corporations, venture capitals and universities and (2) new patent systems which include living forms. Technological and organizational networks are mapped by co-category analysis of empirical data on R\&D collaboration and patent applications. The relation of two maps and the role of the intellectual property systems are also discussed.

\section{1.はじめに}

エレクトロニクスやバイオテクノロジーなどの広義の情報テクノロジーの領域では、知 識の生産が資本蓄積もたらす「情報資本主義」 [Morris-Suzuki, 1986; Castells, 1996:17］の 発展様式が優勢になっていると考えられる。そのような領域では、情報テクノロジーの構 造、研究開発組織間のネットワーク、知的所有権システムの三者の相互作用が、新たな科 学技術の形成に重要な役割を果たしていることを既に論じた [大塚，1997］。局所的な知 識や物を統合することのできる非局所的に流通可能な知識や物としての情報は、同時に、 異なった領域の組織や人を結び付けるであろう。そして、その逆も有り得る。言い替える と、知識や物のネットワークとしての科学技術と、組織や人のネットワークはパラレルに 形成される。ただし、そのためには、情報の専有や流通・蓄積を可能にする諸制度が要請 されるであろう。バイオテクノロジーの領域では、特許制度の生物への拡張や独占禁止政 策の緩和のなかで、DNAの塩基配列が非局所的に流通可能な情報として機能したと考え られた。本論文は、この考察を具体的な事例において検証する。すなわち、1990年代に開 発された遺伝子組み替え作物と、やはり近年急速に整備された生物の特許制度に着目し、 その新たな科学技術において形成される物のネットワークと研究開発組織のネットワーク の関係を、植物特許を媒介にして見てゆきたい。

\section{2. 課題：物と社会}

従来、社会構築 (構成) 主義の立場をとる科学技術の社会学では、人工物や自然物がど のようにして社会的に構築されているか、が一つの課題となってきた。それに対して、カ ロンやラトゥールらは、人による物の社会的な構築に加えて、物による人や社会の科学技 
術的な構築を視野にいれ、両者を対称的に記述することが必要であることを強調した [Callon， 1986; Callon and Latour, 1992]。ラトゥールによると、対象としての「自然」も、それら を構築する主体としての「社会」も、人や物が「アクター」として相互作用する行為のネ ットワークから抽象化されたものに過ざない [Latour, 1993]。このネットワークは、ある 特定のアクターが他のアクターを動員して一定の関係のもとに配置することで成立する。 この意味では、科学技術は物や人の「地図」として、「自然」や「社会」を構筑する行為 であるとも言える。

このプロセスは単一のアクターによってではなく、異なった「社会的世界」を有する複 数のアクターによって協力的にもなされることが考えられる。それを可能にする結節点と して、「シンボリック相互作用論」の流れをくむスターやフジムラらは、「境界対象（boundary objects)」および「パッケージ」の概念を提唱した [Star and Griesemer, 1989; Fujimura, 1992]。「境界対象」は、複数の主体の異なった「社会的世界」の境界にあって、それらの 主体を結び付ける。と同時に、それら諸主体の結合によって、「境界対象」も再構築され る。複数の「境界対象」が諸主体間で共有される場合、それらは結合して「パッケージ」 と呼ばれる科学技術になる。その結果、ラトゥールの場合には同格のアクターとして混在 していた主体と対象が、フジムラらの議論では相互作用する別々の実体となる。すなわち、 一方では諸主体間の社会的ネットワークが構築され、他方では諸対象間の科学技術的ネッ トワークが構築されると考えることが可能であろう。これは、ブルーマーらの「シンボリ ック相互作用論」が、対象をあくまで主体によって構築されるものとして捉えていたのに 対して、対象による主体の変容をも視野に入れる方向への変化である。

ただし、フジムラはネットワークという表現は使わず、対象はアクターではない。本小 論は、この点ではラトゥールの観点に立ち、対象も主体や他の対象に能動的に作用するア クターであり、主体の場合と同様な意味でネットワークを形成しうると考える。すでに主 体として構築されている我々は、このような能動性を、物や知識を組織化しょうとする際 にそれらが時折示す「思いがけない抵抗」(技術的な拘束性や失敗として顕在化)として しか経験することはない。しかし、この「思いがけない抵抗」の存在は、一見主体が構築 したように見える対象のネットワークも、実際には対象側の様々な要因（対象の特性、そ れによる対象間の親和性など）を反映していることを含意する。科学技術や環境の社会問 題を扱う上では、このような対象の能動性を社会学的考察に含めることの利点は小さくな いと考える。

以上のような研究動向を踏まえて、本論文は、構築される対象であると同時に人や組織 を構築する物や知識のネットワーク（＝「パッケージ」）と、企業や大学などの組織のネ ットワークとを、新たな科学技術の研究開発行為において対称的に捉える。その際に、以 上の研究では多くの場合自明視されていた、ある物や知識が特定の人や組織と結びつく過 程がどのような条件に由来するか、という問題に着目する。現代社会においてこの過程は、 一面では、資本主義経済体制における私的所有を正当化する諸規範・制度に媒介されてい る。例えば、フジムラが研究した癌遺伝子理論の形成過程では、異なった研究資源（腫瘍 ウイルス学と発生生物学) を所有する複数の研究室が、境界対象である癌遺伝子の共同研 究によって結び付いていた [Fujimura, 1992: 190-192]。この共同研究は、研究資源の所有 と流通を保証する諸規範・制度、例えば先発見者に対する優先権の規範、学会、専門誌、 
助成金などの諸制度、を前提として成立していた。癌遺伝子は、これらの近代科学に特有 な規範や制度を媒介にして、諸主体間を流通することで、異なった「社会的世界」の諸主 体を結びつけたのである。しかし、この議論では、癌遺伝子が物としてほぼ無限に複製可 能であって、しかもDNA塩基配列という記号を用いた「共通言語」として非局所的に流 通可能であったという、対象側の特性の側面が無視されている [大塚, 1998b]。従って、 癌遺伝子と研究組織を媒介する過程もまた、双方向的なものであったと考えられる。

ところで、このような流通特性を備えた対象は、それが物の形態をとるにせよ知識の形 態をとるにせよ、一般に情報と呼ばれる。もちろん、それが情報と認知されるためには、 主体側の規範や制度の整備が必須である。近年の「情報資本主義」の進展が、エレクトロ ニクスやバイオテクノロジーなどの特定の領域で起きていることは、その領域の物や知識 が情報としての特性を有し、社会的な諸規範・制度がそれを支えているからに他ならない。 バイオテクノロジーの場合は、遺伝子（またはDNA塩基配列）という物（または知識）が、 前述したように情報としての特性を備えていた。そして、この情報およびそれを用いた生 産物は、それらの社会的な認知とともに、それらの私的所有にかかわる諸規範・制度がよ り適合的に変化することによって、ますます諸主体間における流通性を獲得してきた。そ れによって、対象と主体の媒介もより一層進行し、従来では考えられなかったような、諸 対象間・諸主体間のネットワークが形成されることになるであろう。

\section{3. 研究対象：知的所有権システムと遺伝子組み替え作物}

カロンによると、科学技術の形成プロセスは、物を集団に帰す結果として常に帰属過程 を伴う。この帰属過程は、製品を企業に帰属させる法的実体の定義や知的所有権に関する 法制度などとしてコード化されているという [Callon, 1992:85]。本小論の観点からは、 この帰属過程は資本主義経済体制において、また物の抵抗が顕在化しない条件においての み、機能することになる。知的所有権システムは、工業所有権（特許）法を始めとする一 連の知的所有権法およびその取引を規制する独占禁止法、そしてそれらの運用を行う諸組 織などからなる。これらは、出願人や企業などの諸主体間の関係を規定するが、同時に、 どのような物がどの法制度による保護対象となり得るかについての基準、権利主張される 事物の審査を行う基準などの、物相互の関係をも規定する。特許保護の対象物の変化は、 例えば、世界知的所有権機構（WIPO）が5年ごとに改訂する国際特許分類（IPC）におい て端的に認められる。この人工物の分類体系は、現代の資本主義社会における物の秩序の 一つの表現である。このような意味で、知的所有権システムは、所有関係を媒介にして、 物と社会集団が混在する行為の枠組みを作るものと言えよう。

一方で、このシステムは、物と社会集団の相互作用によって形成され変容する。例えば、 本小論で取り上げる農業育種技術の領域では、新種の植物は植物育種者権（日本では農水 省管轄の種苗法）によって権利保護がなされてきた。それが、1980年代に遺伝子組み替え 技術が普及するとともに、微生物、動物、植物が、相次いで工業所有権（通産省管轄の特 許法）の保護下へ移りつつある [大塚, 1996]。この理由としては、遺伝子組み替え技術 によって「発明」した植物の特性は、それらが無限に複製可能でありながら、しかもDNA 配列としてコード化可能であったことのほかに、同技術を最初に所有した企業が主として 医薬品や農薬を製造する多国籍化学企業で、工業所有権制度に強い親和性を持っていた、 
という事情も関係している。実際に、植物育種者権条約、WIPO、ヨーロッパ特許条約な どにおける国際会議は、ヨーロッパの農業保護政策国、種子企業とその業界団体、園芸協 会などの「植物育種者権派」と、アメリカ、工業国の財界団体、化学（医薬・農薬）企業 とその業界団体などの「工業所有権派」の争いの場となり、最終的に後者が勝利を収めた [森山・山下，1989: 843]。すなわち、1988年に「バイオテクノロジー発明と工業所有権に 関するWIPO専門家会議」は、生物が特許保護の対象となる旨を確認した。それを受けて、 1991年には植物育種者権条約も改正され、植物品種は特許と種苗法による二重保護が可能 になった。このように、国際的な利害集団間の競争によって形成された産業組織のネット ワークが、知的所有権システムにおける物のネットワークに反映している。

この新たな知的所有権制度の枠組みにおいては、植物をめぐって、以前とは異なった研 究開発組織および物のネットワークが形成されていることが予想される。すなわち、遺伝 子組み替え作物を事例として選択することにより、新たな特許制度を媒介として、どのよ うなネットワークが物と社会集団の領域で形成されているか、を検討することが可能にな ると考えられた。そこで、本報告では、遺伝子組み替え作物に関連する技術の特許出願に おいて、どのような物間の関係が構築されているか、その一方で、同じ技術に関連して、 どのような組織、とくに多国籍化学企業を中心とする産業組織間の関係がそれらの物の知 的所有権と関連して形成されているか、を明らかにすることを目指す。

付け加えると、遺伝子組み替え作物の科学技術は、当然ながら、知的所有権システムや 企業ネットワークの影響のみを受けている訳ではない。企業が特定の科学技術を開発する 場合、そこにはまず第一に市場、そして国家の規制、場合によってはメディア等に対する 配慮が重要な動機となるであろう。遺伝子組み替え作物の場合も、化学農薬に起因する環 境問題への関心の高まりや規制の強化などが、主要な背景となっていたことを既に論じた [大塚，1998a］。本小論では、このような社会的文脈について重複して言及することは避 け、知識の専有とその流通・蓄積が制度化された経済システムにおいて、科学技術とその 研究開発主体がどのように相互作用するかという問題に焦点を絞りたい。

\section{4. 方法：データと共一カテゴリー分析}

以下のデータを使用した。

A．遺伝子組み替え作物と関連する組織間のネットワーク形成

第一に、1994年から1997年の化学工業日報、日刊工業新聞、日本経済新聞、日経産業新 聞、および日経バイオ年鑑の記事で、遺伝子組み替え作物と関連する研究協力関係（共同 研究、特許のライセンス供与、相互ライセンス、合弁、資本参加、買収、合併）に関する もの。全70件の内訳は、共同研究26件、ライセンス供与14件、相互ライセンス7件、合弁 3 件、資本参加 4 件、買収15件、合併1件であった。第二に、次に示す(2)の特許のうち共同 出願の事例、全8件。以上、合計78件での研究協力関係を分析に供した。

B．遺伝子組み替え作物と関連する物のネットワーク形成

1990年から 1997年の、日本公開特許公報における「創生植物; 開花植物（国際特許分類 $\mathrm{A} 01 \mathrm{H}$ 05/00)」の出願、全257件を用いる。このうち、DNA塩基配列を指定している特許 (識別記号ZNA）は145件で、遺伝子組み替え作物の特許に相当すると思われる。残りの 112件は、遺伝子組み替え技術を直接的には用いない新規作物の特許となる。特許出願に 
際しては、その特許の主張する権利（クレーム）の範囲を明確に規定する必要があり、複 数のクレーム（それぞれ単一の具体的な物または方法からなる）を箇条書に提示する。こ れらのクレームが権利主張する物から、物のネットワークを描出する。

カロンら [Callon et al., 1986] は、科学技術文献で言及されるキーワードの、一つの文 献内での同時的な出現頻度から、キーワード間の関係を抽出して地図化する「共一語分析」 の方法を開発した。この方法は、特許における国際特許分類を用いた分析にも応用されて いる [Engelsman and van Raan, 1994]。本報告の研究対象では、共一語分析を行うにはサ ンプル数が少なく、また国際特許分類では特許庁の解釈を含み分析精度も悪いと考えられ たため、折衷的な共一カテゴリー分析を行った。すなわち、Aでは研究協力関係を締結し た組織を、Bではクレームの主張する物を、以下のようにカテゴリー化した。

A：化学企業、ベンチャー企業、食品および農産物加工（纎維、製紙、タバコ、化粧品 を含む）企業、種子企業、生物農薬企業、大学・公的研究機関の6カテゴリー。

B：遺伝子（遺伝子、DNA配列）、ベクター（遺伝子の「運び屋」として用いるDNA分 子の構築物)、細胞（微生物を含む）、蛋白質（酵素を含む）、植物（一般的な表現で植物 全体を指すもの)、品種（具体的な作物名）、種子（生殖物質、繁殖物質を含む）、生産物 （果実、食品、油脂、薬品、繊維など）の8カテゴリー。

各カテゴリー間の関係は次のように定める。カテゴリーiの出現度数 $\mathrm{Ci}$ 、およびカテゴ リー $\mathrm{j}$ の出現度数 $\mathrm{Cj}$ に対して、同一文献内でのカテゴリー $\mathrm{i}$ と $\mathrm{j}$ 共一出現度数が $\mathrm{Cij}$ のき、 二つのカテゴリーの包含関係の強さを表わす包含インデックスを $\mathrm{Iij}=\mathrm{Cij} / \min (\mathrm{Ci}, \mathrm{Cj})$ と する [Callon et al., 1986]。この包含インデックスと出現度数により、各カテゴリー間の 関係を「地図」化する。

\section{5. 結果と考察：研究開発組織と物的事象の「地図」化}

用いたデータである A と Bの相関を、研究開発組織のカテゴリーについて調べたものを 図1に示す。研究開発組織の特許出願と研究協力関係の締結には、正の相関（相関係数=

図 1 研究開発組織ごとの特許出願と研究協力の相関

相関係数 $\mathrm{r}=0.72$, 回帰式 $\mathrm{y}=0.37 \mathrm{x}+11.9$

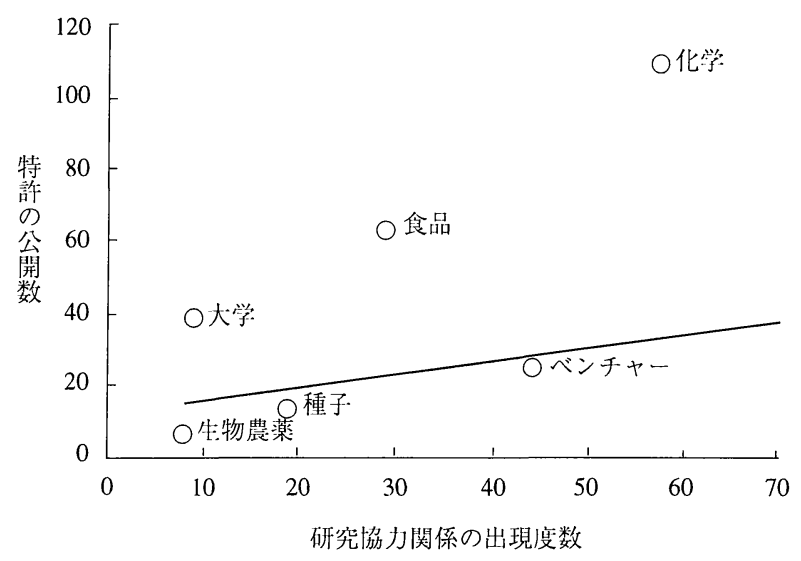


0.72）が示唆された。

すなわち、研究協力関係のネットワーク形成と出願特許における物のネットワーク形成 を関連づけることには妥当性がある。特許出願と研究協力関係の相関には、組織と物の相 互作用という観点から、以下の理由が考えられる。

I. 協力 $\rightarrow$ 特許（組織 $\rightarrow$ 物）：研究協力関係は8件(10\%)の特許共同出願を含む。すなわ ち、少なくとも一部の特許出願は研究協力関係を通じて可能になった。さらに、共同研究 も、一般的に将来の特許出願に関する契約を含む。

II. 特許 $\rightarrow$ 協力 (物 $\rightarrow$ 組織) : 研究協力関係は21件 $(27 \%)$ の特許ライセンス取引を含む。 よって、少なくとも一部の研究協力関係は成立した特許の共同所有を動機としている。資 本参加や買収においても、特許の獲得を動機に含むことが想像される。

以下、本報告では、このような特許を媒介とした協力関係について、特許出願がクレー ムする物相互の関係との相関をみてゆく。

図2 研究開発組織間の協カネットワ 一ク

共一カテゴリー分析による包含関係マ ップ。実線は包含インデックスが 0.5 以上、破線は 0.3 以上 0.5 未満の関係を 示す。矢印の横の数字は両カテゴリー 間の提携件数を、括弧内の数字と相対 的高さは各カテゴリーの全提携件数を 表わす。

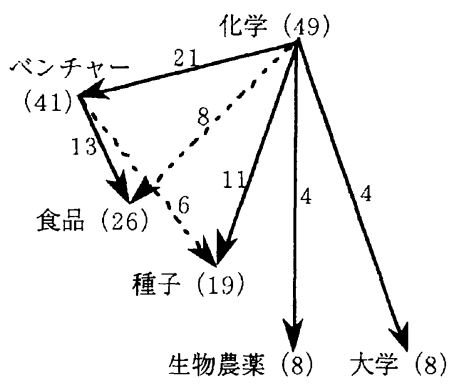

図 3 公開特許における物のネットワーク $\mathrm{a}$ 遺伝子組み替え作物、 $\mathrm{b}$ れ以外の新規作物、に特徵 的な物の共一カテゴリー分析による包含関係マップ。a では包含インデックスが 0.7 以上、bでは 0.5 以上の関係 を示す。記載形式は図 2 と同じ。

a 遺伝子組み替え作物

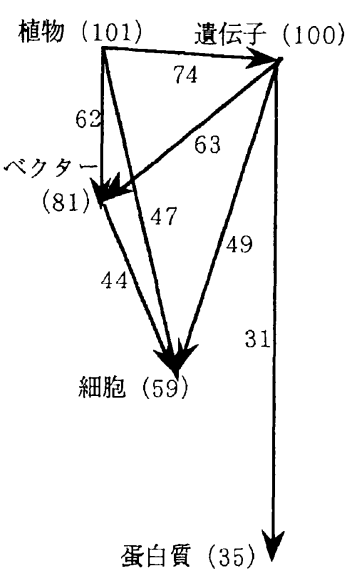

bそれ以外の新規作物

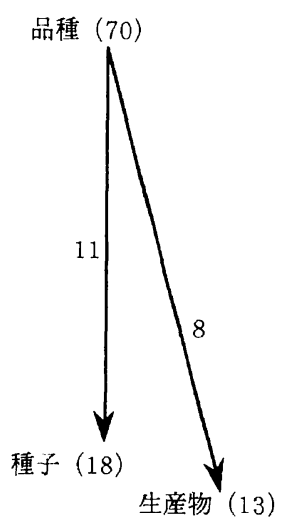

まず、算出した包含インデックスに基づき、組織と物のネットワークを作図し、図 2 お よび図3に示した。各カテゴリーの相対的な高さは出現度数を反映しており、矢印の終点 のカテゴリーは始点のカテゴリーに包含される傾向が強いことを表わしている。図2の研 究協力関係では、化学企業が他のカテゴリーを包含する位置を占めていた。このことは、 遺伝子組み替え作物の開発における組織間ネットワークにおいては、化学企業が中心的な 役割を担っていることを示唆する。これらの化学企業は、欧米系の農薬を製造する多国籍 
企業（多い順にモンサント、ノバルティス、ゼネカ、へキストなど）である。協力関係の 内容も、化学企業がベンチャー企業、種子企業、生物農薬企業に対して買収・資本参加を 行うものが多かった。特許ライセンスについては、ベンチャー企業との関係では相互的ラ イセンスが相対的に多かったが、種子企業に対しては供与している場合が多かった。大 学・公的研究機関との関係は主に共同研究による。また、植物の遺伝子組み替え技術の開 発を専門とするベンチャー企業も、食品・農産物加工企業（および弱いながらも種子企業） に対して、包含的な関係をもっていることがわかった。この関係は、共同研究および食品 によるベンチャーへの資本参加が主であった。

図3の物のネットワークでは、DNA塩基配列を特定する遺伝子組み替え作物の特許と、 それ以外の特許を別個に分析した。遺伝子組み替え作物においては、「植物」 $\rightarrow$ 「遺伝子」

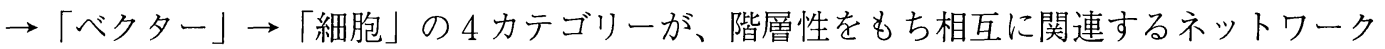
を形成していた。これらは究めて強い包含関係（7割以上が同時に出現する）を有し、一 つの「パッケージ」として用いられていることが示唆される。特許検索の分類が創生植物 であるので、「植物」カテゴリーが上位に来るのは当然だが、それが特定の品種名ではな く植物一般であることが注目される。このネットワークに現われている科学技術は、汎用 性が高いことを窥わせる。ほぼ同等に高頻度のカテゴリーが「遺伝子」で、「蛋白質」を含 む下位のカテゴリー 3 種を包含している点で、中心的な役割を担っていると考えられる。

図 4 各組織の特許一件あたりの平均クレーム数

特許一件あたりで物の各カテゴリーの所有権主張数を平均し、レーダーチャートに示した。 （）内の数字は各組織の出願特許件数を表わす。
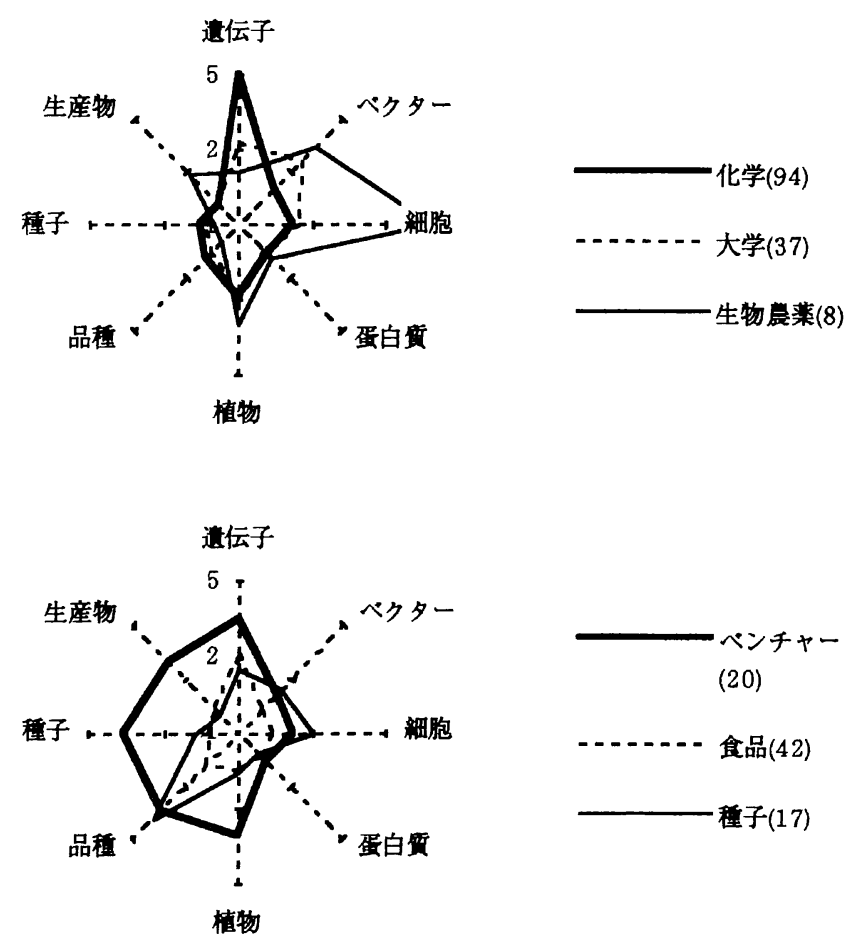
遺伝子組み替え以外の新規作物の特許では、より弱い包含関係ではあるが、「品種」カ テゴリーによる「種子」と「生産物」の統合が認められた。このネットワークは、従来型 およびその発展型の品種改良技術を表わしていると考えられ、遺伝子組み替え作物の主張 する物のネットワークとは全く異なるものであることがわかる。

次に、これらの組織と物のネットワークの関連について検討する。特許のクレームは、 物相互のネットワークと同時に、組織による物の所有関係を指示する。図4は、各組織が 所有権主張する物のパターンを表わす。「遺伝子」の所有志向が最も強い組織は化学企業 で、次にベンチャー企業が続く。「ベクター」は、大学・公的研究機関と生物農薬企業が 重点を置いている。また、菌体を商品として開発する生物農薬企業は、「細胞」のクレー ムで突出している。一方、種子企業は「品種」に特化して出願しているが、食品・農産物 加工企業はこれといった特徴がなく、同様に広範な物を所有するべンチャー企業に平均ク レーム数の上で包含されている。

以上の結果から、図2と図3の関係を類推することが可能である。第一に、「植物」 $\rightarrow$ 「遺伝子」を軸とする遺伝子組み替え作物の物のネットワークの統合は、化学企業を中心 とする組織間ネットワークに対応している。化学企業は1980年代から、大学や創生期の遺 伝子組み替えべンチャー企業（ここで取り上げている農業関連のベンチャーとは異なる） に投資し、分子生物学的な遺伝子関連技術を既に内部化していた。化学企業は最も統合力 の強い物である「遺伝子」を所有することで、組織間ネットワークの中心となることがで きたであろう〈II. 特許 $\rightarrow$ 協力 (物 $\rightarrow$ 組織) のパターン〉。同様にして、二番目に「遺伝 子」の所有志向の強いベンチャー企業が、組織間ネットワークにおいても第二の位置を占 める。化学企業とベンチャー企業、ベンチャー企業と食品企業の間では、特許のライセン ス契約のうち相互的ライセンスの比率が他の関係に比べて相対的に高いことも、この可能 性を裏付けるものである。すなわち、「遺伝子」特許のライセンスと交換に、他の物の特 許権を獲得するケースが多く認められる。このようなパターンとは逆に、化学企業が他の 組織を資本や他の無形資産によって統合することで、「遺伝子」を中心とする特許を成立 させた場合もあるだろう〈I. 協力 $\rightarrow$ 特許（組織 $\rightarrow$ 物）のパターン〉。化学企業とベンチャ 一企業や大学との関係で、投資を伴う共同研究や共同出願が多いことは、この可能性を示 唆する。いずれの場合でも、化学企業が歴史的に最も特許制度と親和性が強く、「遺伝子」 による生物の特許化を可能にした経緯が、この組織と物の対応関係に大きな影響を及ほし ていると考えられる。

第二に、「品種」を「種子」や「生産物」に媒介寸る遺伝子組み替え以外の品種改良技 術は、種子企業およびベンチャー企業によって担われている。これらの企業は、「品種」 に加えて「細胞」のクレームも多く、植物細胞の培養から新品種を作出する科学技術を内 部化していると思われる。この物のネットワークは遺伝子組み替え作物についての物のネ ットワークとは相対的に独立に存在する弱い関係であり、図3のa と消失してしまう。だが、両者は技術的には補完的である。実際の商品としての作物や種 子の開発では、遺伝子組み替え技術で可能となる「植物」を特定の「品種」に展開する必 要があり、また植物細胞培養による品種改良は遺伝子組み替え技術を利用することによっ て効率が大幅に向上する。よって、化学企業と種子企業との関係は、共同研究、共同出願 が少なく、投資とライセンス契約が多くなっている。この関係は、〈II. 特許 協力（物 


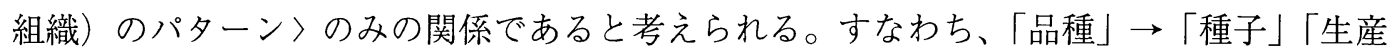
物」の関係は、化学企業 $\rightarrow$ 種子企業の関係に反映されているが、その逆は十分に成立して いない。故に、物のネットワークでは、図3のaとbのネットワークは相対的に独立に存在 することになっていると思われる。たたし、種子企業と化学企業の関係は、全 11 件中 9 件 が1996年以降のものであり、今後はこの組織間関係を反映した物のネットワークも出現す るであろう。

\section{6. モンサントの企業ネットワーク}

以上の考察をさらに確証するために、特定の企業の協力関係に関する事例を見てみよう。 図5は、研究協力関係のデータで最も件数の多かったモンサント社（米国の化学企業）の ケースを示す。図5に示した資本系列企業は、医薬部門子会社のG.D.サールを除くと、全 て1996年以降に買収した企業である。その多くが、種子企業およびベンチャー企業であっ た。食品企業および生物農薬との関係は、資本系列化に至るまでのものではない。

ベンチャー企業との関係は、買収以前に、特許ライセンス取引を含むものであった。例 えば、植物の遺伝子組み替えベンチャーであるカルジーンやアグラシータスとは、1990年 代初めから植物遺伝子組み替え技術の基本特許をめぐって特許係争を続けていた。カルジ ーンとは、1993年に大規模な相互的ライセンス契約が成立し、その後、資本参加と研究協 力関係に発展していた。1996年におけるカルジーンとアグラシータスの買収は、前年に会

図 5 多国籍化学企業モンサント社（本社：米国セントルイス）の主要な企業ネットワーク 実線は買収または資本参加、破線はライセンス取引または研究協力、矢印実線は売却を示す。

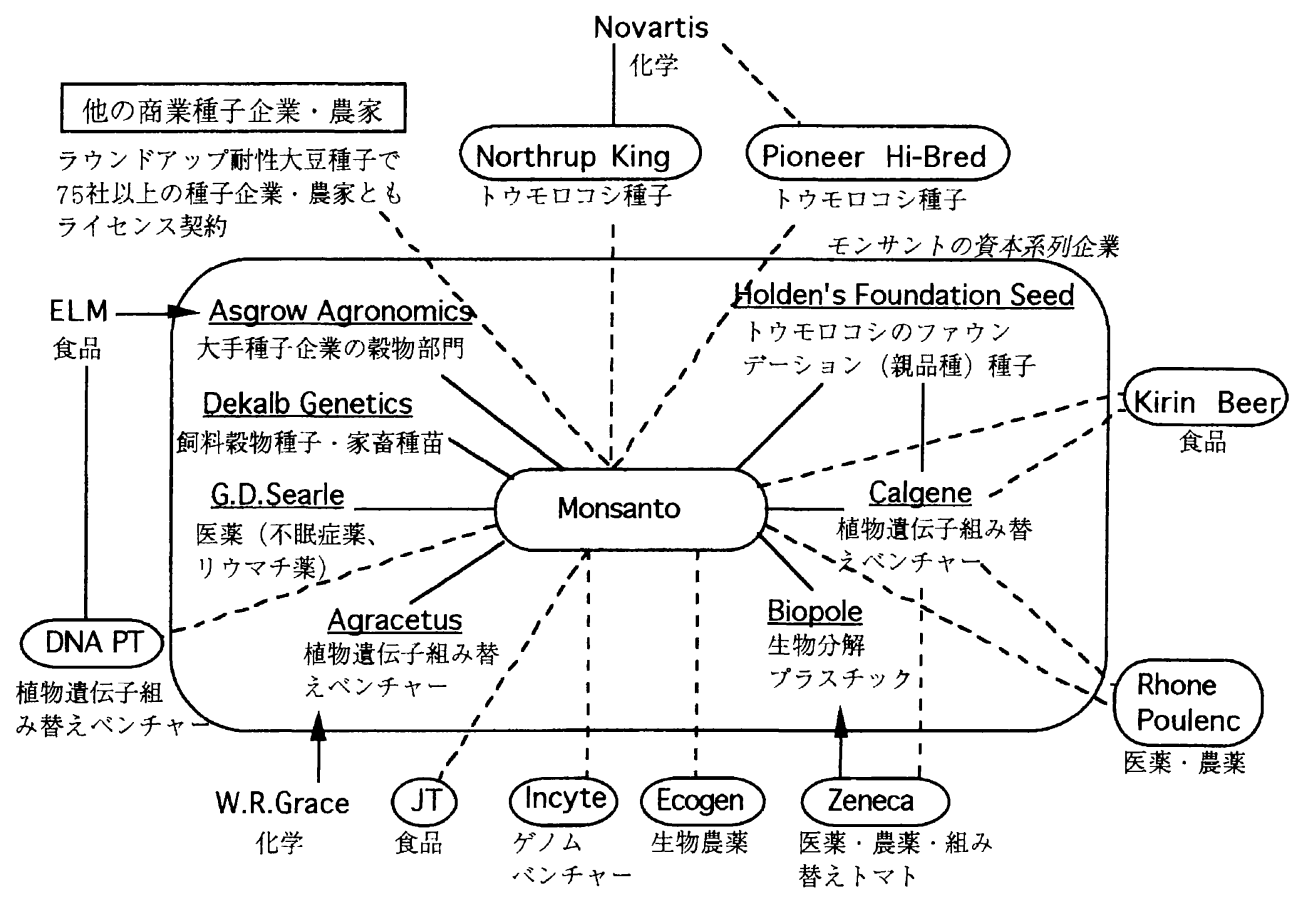


長兼社長に就任したシャピロ（Shapiro, Robert）の経営理念やベンチャー側の資金難とい つた要因もあったが、知的所有権をめぐる多国籍企業による内部化の一つのパターン（特 許係争 $\rightarrow$ 協力 $\rightarrow$ 買収）として理解できるであろう。協力から買収への展開は、内部化によ る取り引きコストの削減として説明できる。そして、特許係争は相互的ライセンスなどの 協力関係による、補完的な知的所有権や無形資産の獲得を意図して行われたと考えられる。 同様に、DNA-PT（プラント・テクノロジー）との研究協力関係も、モンサントが特許権 の侵害で提訴したことから始まっていた。提訴された時点でDNA-PTの広報担当者は、こ の訴訟が「モンサントの取り引き戦略の一環」で、両者とも法廷外での和解を望んでいる 点を強調していた [Supermarket News, 1945, 45(22): 22]。

特許係争 $\rightarrow$ 協力 $\rightarrow$ 買収という構図においては、買収する側の企業が何らかの特許、すな わち物のネットワークに参入可能な物、を所有していることが必要条件である。図3、図4 でみたように、化学企業は「遺伝子」を最も強力に権利主張することによって、下位カテ ゴリーの物を所有する組織に対して有利な状況にあった。モンサントの場合、1983年に取 得した植物遺伝子組み替え技術の基本特許（プロモーターと選択マーカーの「遺伝子」に 関する）がこの領域の標準化技術として機能することになり、その後の物と組織のネット ワーク形成に決定的な役割を果たした。この特許は、細菌の遺伝子組み替え技術から基本

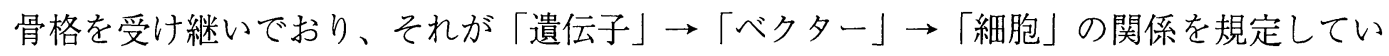
た。モンサントは、1970年代後半から大学 (ハーバード大医学部、ワシントン大学) やベ ンチャー企業（ジェネンテック）へ投資して、遺伝子組み替え技術における物のネットワ 一クを内部化していた。1983年の基本特許も、ワシントン大学との研究協力関係に基づい ていた。さらに、この特許における物のネットワークは、モンサントやワシントン大によ る、「植物」への応用法のプロモーション（例えば、この特許の「遺伝子」に適合的なノ ウハウであるリーフ・ディスク法のワークショップ）やライセンス供与を通じて、利用さ

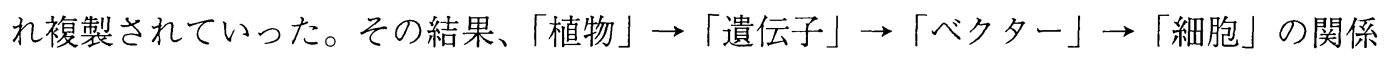
が、他の組織の特許出願においても踏襲されて、全体として安定化することになったと考 えられる。すなわち、植物遺伝子組み替え技術の物のネットワークは、フジムラの言う 「パッケージ」として機能し、研究組織間のネットワーク形成を促進した。

一方、モンサントによるデカルブ、アスグロウ、ホールデンなどの研究開発型の種子企 業の資本統合も、知的所有権の内部化動機から説明できる。モンサントや系列化したベン チャー企業が開発した植物遺伝子組み替え技術は、最終的には商品作物の種子として製品 化する。その際に、特定の「遺伝子」を導入するための「品種」や「種子」が必要になる。 「品種」の知的所有権は、1991年の植物育種者権条約の改正で特許との二重保護が可能に なったが、それまでは、特許ではなく植物育種者権によって研究開発型の種子企業が所有 してきた。このために、特許における物のネットワークでは、化学企業を中心とする図 $3 \mathrm{a}$

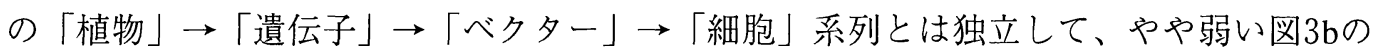
「品種」 $\rightarrow$ 「種子」「生産物」系列の関係が存在していた。モンサントによる種子企業の資 本統合は、この独立した弱いネットワークをも内部化しようとするものであると考えられ る。その結果、将来には「遺伝子」と「品種」間の関係も構築される可能性があるであろ う。付言すると、図5の商業種子企業・農家との関係は、モンサントによる一方通行的な ライセンス供与で、特許料の獲得を動機としている。 


\section{7. 今後の展望}

研究開発という行為は、物と人を組織することを通じて、一方では物相互のネットワー クを形成し、他方では研究開発を行う組織間のネットワークを構築する。本小論では、両 方のネットワークを「地図」として表わし、それらの対称性を論じた。この対称性は、あ る特定の物が特定の組織に専有され、かつ異なった組織間で非局所的に流通可能であるこ とによって保証されると考えられた。すなわち、情報としての性質をもつ物が、特許制度 や競争政策などの知的所有権システムに組み込まれることである。そのような場合、情報 としての物は異なった組織を結び付ける一方で、各組織に固有の異なった諸物が情報とし ての物を中心に再組織される。そして、この相互的な過程において、ある程度安定化した 一方のネットワークは、互いに他方のネットワークの構築に影響を与えるであろう。

1990年以降の遺伝子組み替え作物の開発においては、組織のネットワークにおける化学 企業の優位が、物のネットワークにおける「遺伝子」の優位と相互に関連していることが、 諸組織の研究協力および特許出願のデー夕から抽出できた。これは、特許における化学企 業による「遺伝子」の専有を媒介として、一方の優位が他方の優位を根拠づける仕方で発 展してきていることを示すものと考えられた。この相互的な作用は、一方で、特許や植物 育種者権における物のネットワークが、それらの専有を基準として起きる競争とその結果 として現われる研究協力や買収に基づく組織のネットワークに認められた（例：モンサン トによるベンチャー企業との特許係争 $\rightarrow$ 提携 $\rightarrow$ 買収)。また、他方で、研究協力や買収と して現われる組織のネットワークが、共同研究や共同出願を通して物のネットワークに反 映されていると考えられた（例：モンサントと大学の協力関係が植物遺伝子組み替え技術 の基本特許として結実 ; モンサントによる種子企業の買収が将来の「遺伝子」 $\rightleftarrows$ 品種」 関係をつくる可能性)。

結局、このような知識の専有で媒介される物と組織のネットワークは、階層的なものと なる。「情報資本主義」は、ライセンス関係が資本統合に転化する過程を経て、カステル が論じたような多国籍企業の寡占的支配 [Castells, 1996:192] に帰着するであろう。それ は他方では、階層性をもった物の関係が一まとまりとなって、すなわち標準的な「パッケ ージ」として流通することに対応する。このような現象は、モリス鈴木の言い方を借りる と、「科学を市場性のある商品に転換するために、知識は特定の標準化された様式で表わ さなければならなくなる」ため、「情報資本主義」では知識の構造そのものも変化する [Morris-Suzuki, 1986=1997: 69] と把握できるであろう。

但し、そのような相互作用から生じる階層性には、いくつかの初期条件が関与している ことも示唆された。すなわち、「遺伝子」を中心とする「ベクター」や「細胞」などの物 のネットワークは、1983年のモンサントによる植物遺伝子組み替え技術の基本特許におい て、すでに「パッケージ」として安定化していた。さらに、それは1973年の微生物を用い た遺伝子組み替え技術に遡ることができる。1990年代における遺伝子組み替え作物におけ る物のネットワークは、これらの既存の「パッケージ」が標準化してゆくことを通じて形 成されたと考えられる。また、化学企業を優位とする研究開発組織間の関係は、化学企業 が巨大な多国籍企業であって、医薬部門と農薬部門を併せ持っていたこと、世界各地の研 究所を通じた大学やベンチャー企業との幅広い研究協力ネットッワークをすでに所有して いたことなどによって、すでに半ばその概形ができ上がっていた。これらの組織のネット 
ワークが、特許による「遺伝子」という物の専有における優位を通じて、種子企業、生物 農薬企業、食品企業などとの新たな関係に結び付いて行ったと考えられる。

このような初期条件の影響力を考慮すると、過去に形成された物や組織のネットワーク が、現在にとって重要であることがわかる。すなわち、物や組織のネットワークは、白紙 の空間に突然生じるのではなく、時間の継起のなかで相互に影響を及ぼしつつ変化するも のと考えることが妥当であろう。本報告では、1990〜97年という時間を一つの空間として 「地図」化したが、今後はより長い時間におけるこのような「地図」の変化を捉えること が必要であると思われる。

\section{文献}

Callon, Michel 1986 "The Sociology of an Actor-Network: The Case of the Electric Vehicle," in Michel Callon, John Law \& Arie Rip (eds.), Mapping the Dynamics of Science and Technology, Macmillan Press, pp.19-34.

1992 "The Dynamics of Techno-Economic Networks," in Rod Coombs, Paolo Saviotti \& Vivien Walsh (eds.), Technical Change and Company Strategies: Economic and Sociological Perspectives, Academic Press, pp.72-102.,

John Law \& Arie Rip 1986 "Qualitative Scientometrics," in Michel Callon, John Law \& Arie Rip (eds.), Mapping the Dynamics of Science and Technology, Macmillan Press, pp.103-123.

— \& Bruno Latour 1992 "Don't Throw the Baby Out with the Bath School!: A Reply to Collins and Yearley," in Andrew Pickering (ed.), Science as Practice and Culture, The University of Chicago Press, pp.343-368.

Castells, Manuel 1996 The Information Age: Economy, Society and Culture Volume I: The Rise of the Network Society, Basil Blackwell.

Engelsman, E. C. \& A. F. J. van Raan 1994 “A patent-based cartography of technology," Research Policy 23: 1-26.

Fujimura, Joan H. 1992 "Crafting Science: Standerized Packages, Boundary Objects, and "Translation" ," in Andrew Pickering (ed.), Science as Practice and Culture, The University of Chicago Press, pp.168211.

Latour, Bruno, 1993, We Have Never Been Modern, Harvard University Press.

Morris-Suzuki, Tessa 1986 "Capitalism in the Computer Age," New Left Review 160: 81-91.= 1997 in Jim Davis, Thomas Hirschl \& Michael Stack (eds.), Cutting Edge: Technology, Information, Capitalism and Social Revolution," Verso, pp.57-71.

森山昇・山下洌 1989 「バイオテクノロジー発明と工業所有権に関する第 4 回WIPO専門家会議につい て」『特許管理』39(7): 835-845.

大塚善樹 1996 「バイオテクノロジーと第三世界」『社会学評論』47(3): 378-394.

—— 1997 「情報資本主義」におけるテクノロジーの秩序一知的所有権を媒介とする多国籍企業の 協力的ネットワークの形成」『年報社会学論集』10:97-108.

——1998a 「遺伝子組み替え作物をめぐる環境問題と科学技術の相互的構築」『環境社会学研究』 4: $93-108$

——1998b 「メディアとしての遺伝子—科学技術の文化研究の視点から」『Sociology Today』9: 43-58.

Star, Susan Leigh \& James R. Griesemer, 1989, "Institutional Ecology, "Translations" , and Boundary Objects: Amateurs and Professionals in Berkeley' s Museum of Vertebrate Zoology, 1907-39," Social Studies of Science, 19: 387-420. 